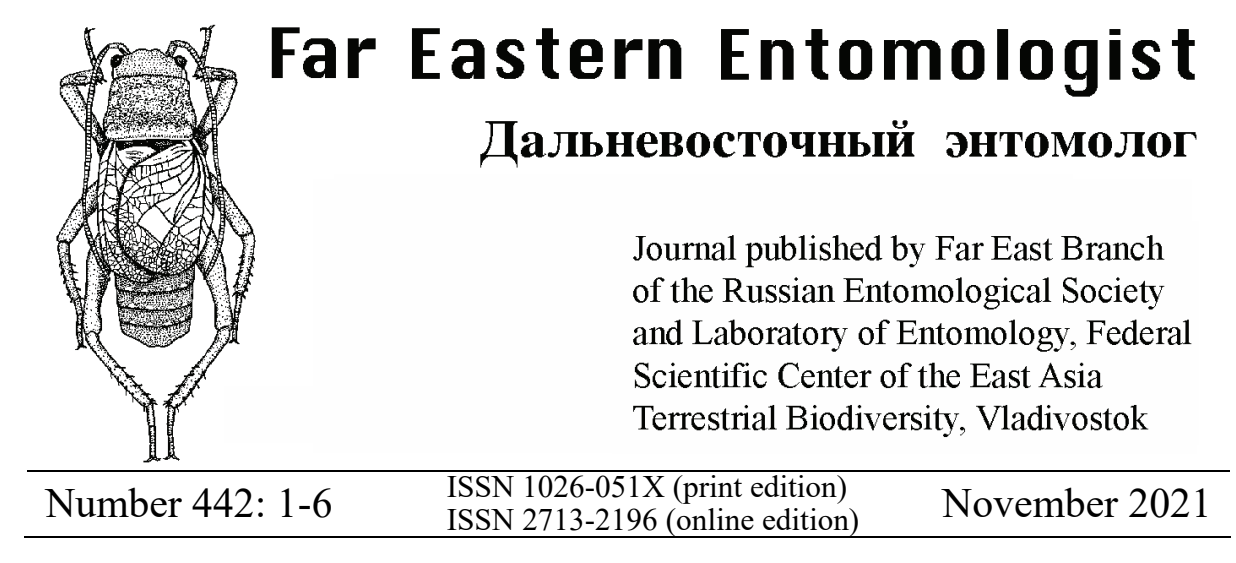

https://doi.org/10.25221/fee.442.1

http://zoobank.org/References/E28FB710-C8A8-46DA-857B-FE1D96859535

\title{
A NEW SPECIES OF THE GENUS CARYANDA STÅL, 1878 (ORTHOPTERA: ACRIDIDAE) FROM THAILAND
}

\section{S. Yu. Storozhenko}

Federal Scientific Center of the East Asia Terrestrial Biodiversity, Far East Branch of the Russian Academy of Sciences, Vladivostok, 690022, Russia.E-mail: storozhenko@biosoil.ru

Summary. Caryanda zheminzhengi sp. n. is described and illustrated from Thailand. The new species is similar to C. beybienkoi Storozhenko, 2005 but differs by the cingular valves of penis equal to apical penis valves and by completely red hind tibia, while in $C$. beybienkoi the cingular valves of penis distinctly longer than apical penis valves and hind tibia blue and red.

Key words: grasshoppers, taxonomy, new species, South East Asia.

А С. Ю. Стороженко. Новый вид рода Caryanda Stål, 1878 (Orthoptera: Acrididae) из Таиланда // Дальневосточный энтомолог. 2021. N 442. С. 1-6.

Резюме. Из Таиланда описан Caryanda zheminzhengi sp. n. Новый вид сходен с C. beybienkoi Storozhenko, 2005, но отличается от последнего короткими верхними створками пениса и красными задними голенями (у C. beybienkoi верхние сворки пениса длиннее нижних, а задние голени красно-голубые).

\section{INTRODUCTION}

The genus Caryanda Stål, 1878 consists of 88 species distributed mainly in Oriental region with a few species in East Palaearctic and Afrotropical regions (Cigliano et al., 2021), while only six species are known from Indo-China (Storozhenko, 2005). New species from Thailand is described below. 


\section{MATERIAL AND METHODS}

This paper is based on specimens collected by Dr. V.G. Bezborodov in Thailand in 2009. The morphological terminology and measurements followed those of Uvarov (1966) and Storozhenko et al. (2015). The terminology of male genitalia followed those of Dirsh (1956).

Photographs were taken with an Olympus SZX16 stereomicroscope and an Olympus DP74 digital camera, and then stacked using Helicon Focus software. The final illustrations were post-processed for contrast and brightness using Adobe ${ }^{\circledR}$ Photoshop ${ }^{\circledR}$ software. The holotype of new species is deposited at the Zoological Institute of the Russian Academy of Sciences, St. Petersburg (ZISP).

\section{DESCRIPTION OF NEW SPECIES}

Caryanda zheminzhengi Storozhenko, sp. n.

http://zoobank.org/NomenclaturalActs/5DD04AD9-64B8-4EA6-A400-0C2DEDCE21C5

Figs 1-5

MATERIAL. Holotype: $\widehat{\jmath}$, Thailand: prov. Nakon Savan, $12 \mathrm{~km}$ S Mae Wong, $15^{\circ} 46^{\prime} 5^{\prime \prime}$ N, 99 $32^{\prime} 0^{\prime \prime}$ E, 8-9.VIII 2009, coll. V. Bezborodov (ZISP). Paratype: ㅇ, the same label as holotype (ZISP).

DESCRIPTION. Male. Body slender, medium-sized for the genus. Head distinctly shorter than pronotum. Frons and genae rugosely punctured; vertex and occiput smooth. Face in profile reclinate. Frontal ridge distinct almost to clypeal margin, deeply sulcate, slightly narrowed near median ocellus. Vertex between eyes as broad as maximal width of frontal ridge. Fastigium of vertex short; foveolae absent. Eyes large, oval; vertical diameter of eye 3.4 times as long as subocular furrow. Antennae 23-segmented, reaching the base of mid femora; mid segments of antennae 2.8-3.0 times as long as width. Pronotum punctured, crossed by three transverse furrows; median and lateral carinae vestigial; prozona 2.25 times as long as metazona; anterior margin of prozona not excised near median carina; posterior margin of metazona broadly rounded. Prosternal spine straight, conical, with pointed apex. Mesosternal lobes square, mesosternal interspace narrow, 3.0 times as long as wide; metasternal lobes fused. Tegmina lateral, not touching each other in a resting position, reaching the base of 2nd abdominal tergite, 2.1 times as long as wide; apex of tegmen rounded. Hind wings absent. Hind femora slender, 4.5 times as long as their maximal width; dorso-median carina smooth; ventral genicular lobes with spine. Hind tibiae with 9 outer and 9 inner dorsal spines; outer apical dorsal spine very small. Hind tarsi short, not longer than the half of hind tibiae; third segment (without claws) as long as basitarsus; arolium large, surpassing apex of claws. Tympanum large, oval. 10th abdominal tergite without furculae on posterior margin; supra-anal plate trapezoid, as long as its width near base, with triangular apex; its surface slightly concave near the base. Cerci overreaching the supra-anal plate, conical, with pointed apex, 3.0 times as long as their width near base. Subgenital plate short. 


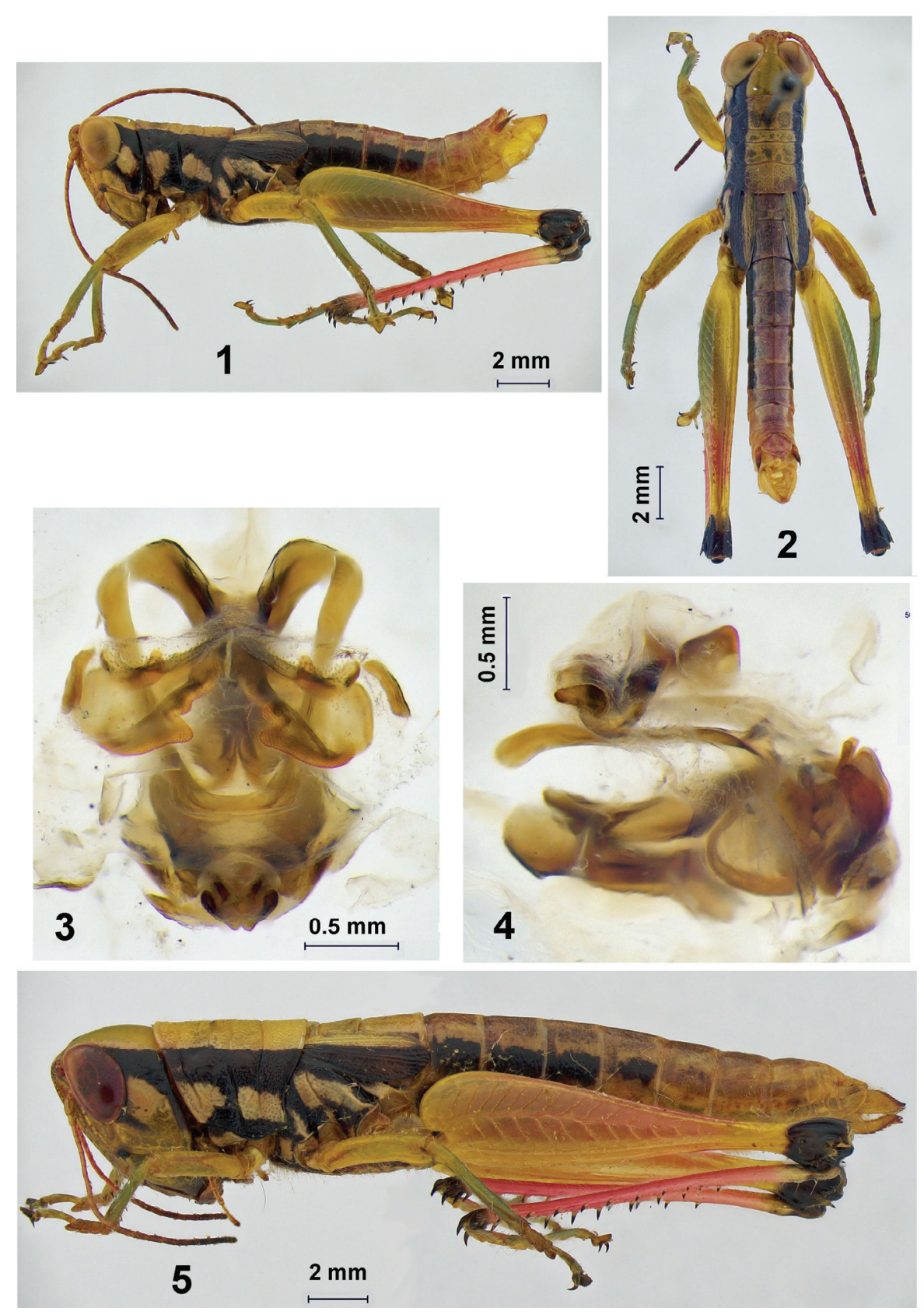

Figs 1-5. Caryanda zheminzhengi sp. n. 1-4-male (holotype): 1 - body, lateral view; 2 - the same, dorsal view; 3 - genitalia, dorsal view; 4 - the same, lateral view; 5 - female (paratype), body, lateral view. 
Epiphallus bridge-shaped; bridge broad and completely divided; ancorae relatively short, triangular; anterior projections as long as ancorae; posterior projections broadly rounded; lophi of epiphallus great, extending, with enlarged outer and distinct inner lophi; oval sclerites elongated. Cingulum sclerotised, consisting of almost straight apodemes, zygoma, and narrow rami; zygoma straight apically, covering the arch of cingulum. Valves of cingulum divided, parallel-side, apically with rounded apex. Apical valves of penis lobe-like with rounded apex, almost as long as cingular valves; basal and apical penis valves connected by a strongly curved, unbroken flexure.

Body yellowish green with black marks (Figs 1,2). Dorsal side of head yellowish green; genae yellow with black vertical stripe; postocular stripe black; face yellow with numerous small brown dots; mandibles yellow with brown apex. Basal half of antennae light brown, apical part dark brown. Disc of pronotum yellowish green; lateral lobes black with two yellow spots. Tegmina black with light stripe along posterior margin. Fore and mid femora yellow; for and mid tibia bluish. Hind femur yellowish green with reddish apical part; dorsal and ventral genicular lobes black. Hind tibia red with black and yellow base and blackish apex; dorsal spines with black apex. Hind tarsi bluish. Abdomen dorsally light brown; 9-10th abdominal tergites and supra-anal plate brownish; cerci brown with blackish apex; lateral side of 1 st-5th tergites with black stripe. Abdomen ventrally yellow; sternal plate with black margins; subgenital plate yellow.

Female. Similar to male, but larger. Head distinctly shorter than pronotum. Frons rugosely punctured; genae, vertex and occiput smooth. Face in profile reclinate. Frontal ridge distinct almost to clypeal margin, deeply sulcate, slightly narrowed near median ocellus. Vertex between eyes almost as broad as maximal width of frontal ridge. Fastigium of vertex short; foveolae absent. Eyes large, oval; vertical diameter of eye 2.7 times as long as subocular furrow. Antennae 23-segmented, reaching the base of fore femora; mid segments of antennae 3.0 times as long as width. Pronotum as in male but prozona 2.4 times as long as metazona and posterior margin of metazona almost straight. Prosternal spine straight, conical, with pointed apex. Mesosternal lobes 1.1 times as wide as long; mesosternal interspace 2.5 times as long as wide; metasternal lobes fused. Tegmina lateral, reaching the base of 2 nd abdominal tergite; 2.0 times as long as wide. Hind wings absent. Hind femora as in male, 4.5 times as long as their maximal width. Hind tibiae with 9 outer and 10 inner dorsal spines; outher apical dorsal spine very small. Hind not longer than the half of hind tibiae; third segment (without claws) as long as basitarsus; arolium large, surpassing apex of claws. Tympanum large, oval. 10th abdominal tergite deeply excised; supra-anal plate triangular, almost as long as its width near base. Cerci reaching apex of supra-anal plate, conical, with pointed apex, 2.7 times as long as their width near base. Subgenital plate elongated, 1.4 times as long as wide, with triangular posterior margin. Ovipositor short; dorsal valves as long as lower ones, dentate; ventral valves slightly curved and also dentate.

Body colored as in male, but genae below eyes with narrow black stripe, dorsally abdominal tergites and supra-anal plate greenish yellow, cerci light brown with blackish apex, abdomen ventrally yellowish green, and ovipositor light brown with black spines. 
MEASUREMENTS (length in mm). Body: male 192.5, female 27.0; antenna: male 8.6, female 9.70; pronotum: male 3.9, female 5.2; tegmen: male 3.35, female 4.2; hind femur: male 11.3, female 14.5; ovipositor 1.9.

DIAGNOSIS. The new species is most similar to Caryanda beybienkoi Storozhenko, 2005 from Thailand (Fig. 6) but easy recognizable from latter by short cingular valves of penis and color of hind tibia and tarsi (in C. beybienkoi, the cingular valves of penis distinctly longer than apical penis valves, basal third of hind tibia blue, apical part of tibia and basitarsus red). From C. tamdaoensis Storozhenko, 1992 and C. azurea Gorochov et Storozhenko, 1994 (both from Vietnam), C. zheminzhengi sp. n. differs in the color of hind tibia and the shape of cingular valves and apical penis valves (in the latter Vietnamese species, hind tibia are blue and both valves are long and narrow). The new species is also similar to $C$. spuria Stål, 1861 from Java and C. neoelegans Otte, 1995 from Vietnam and South China in the red hind tibia, but differs from the former in the lobe-like apical penis valves (in C. spuria, valves are long and with parallel sides) and from the latter in the rounded apex of valves of cingulum (in $C$. neoelegans, valves are pointed apically).

DISTRIBUTION. Thailand: province Nakon Savan.

ETYMOLOGY. New species is named in memory of professor Zhe-Min ZHENG (1932-2021), a founder of Chinese acridology.

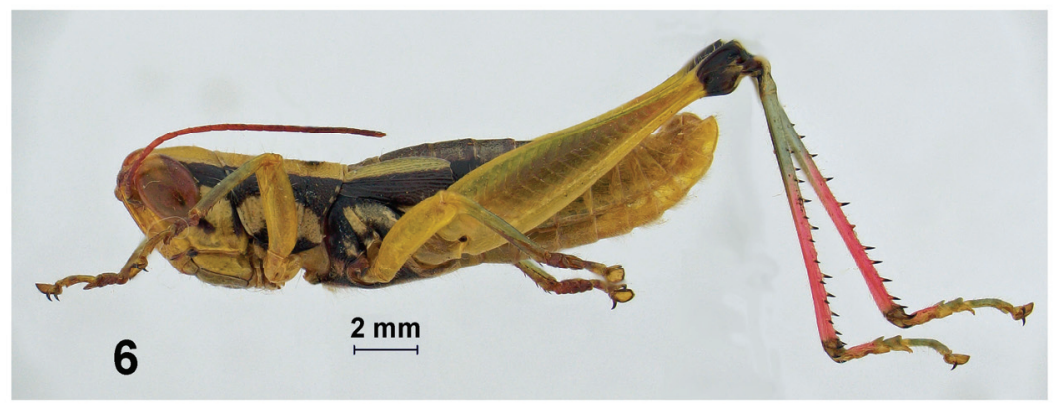

Fig. 6. Caryanda beybienkoi Storozhenko, 2005 (paratype, male from Thailand: prov. Phetchaburi, environs of National Park Kaeng Krachan, $12^{\circ} 45^{\prime} 0^{\prime \prime}$ N, $99^{\circ} 36^{\prime} 0^{\prime \prime}$ E).

\section{ACKNOWLEDGEMENTS}

I thank Dr. Vitaly Bezborodov (Blagoveshchensk, Russia) for providing specimens and to Dr. V.M. Loktionov (Federal Scientific Center of the East Asia Terrestrial Biodiversity, Vladivostok) for help with preparing photos.

\section{REFERENCES}

Cigliano, M.M., Braun, H., Eades, D.C., \& Otte, D. 2021. Orthoptera Species File Online. Version 5.0/5.0. Available from: http://Orthoptera.SpeciesFile.org. (Accessed: 25 October 2021). 
Dirsh, V.M. 1956. The phallic complex in Acridoidea (Orthoptera) in relation to taxonomy. The Transactions of the Royal Entomological Society of London, 108, 223-356. DOI: https://doi.org/101111/j.1365-2311.1956.tb0227.x

Storozhenko, S.Yu. 2005. New grasshoppers of the subfamily Catantopinae (Orthoptera, Acrididae) from Thailand. Proceedings of the Russian Entomological Society. St. Petersburg, 76: 79-91. [In Russian with English summary]

Storozhenko, S.Yu., Kim, T.W. \& Jeon, M.J. 2015. Monograph of Korean Orthoptera. National Institute of Biological Resources, Incheon. 377 pp.

Uvarov, B.P. 1966. Grasshoppers and locusts. A handbook of general acridology. Vol. 1, anatomy, physiology, development, phase polymorphism, introduction to taxonomy. University Press, Cambridge, $481 \mathrm{pp}$. 